\title{
Reflection the Archaisms in Translations of "Baburname"
}

\author{
Khoshimova Dildora Madaminovna
}

\author{
Doctor of Science, Namangan Engineering and Technology Institute, Namanagan, Uzbekistan \\ dxoshimova@mail.ru, dildorakhoshimova@gmail.com
}

\begin{abstract}
ANNOTATION
This article is devoted to the translation of archaeologists in the text of "Baburname". The problems that reflecting in the translation of archaic words and their methods of solving. The information was given about the archaic words marked the original text is a pragmatic factor.

Babur was the greatest writer in the Turkic language, from the earliest examples to classical forms and perfectly utilizing their finest examples in his work. At the same time, he has succeeded to reach the subtle levels of Arabic and Persian languages, his poetry, scientific-historical work, and especially the "Baburname". In this regard, the importance of the ancient Turkic language, which is the basis of the language in "Baburname".
\end{abstract}

According to professor Z.Kholmanova's conclusion, more than 1720 general-purpose lexema which are widely used in the ancient Turkic language in "Baburname". In determining the relation of the lexicon to the ancient Turkic language period, words are divided into three groups: 1) Turkish lexemes, widely used in ancient Uzbek literary language; 2) Remedies from the consumption of the old Uzbek literary language; 3) The lexemes formed during the Old Uzbek language [6.P.24]. As you know, archaism is a collection of unusual words that are not used in the real or literary language of a certain age. In this context, the use of archaeologists in the "Baburname" signifies the author's deep knowledge and linguistic experience in language history.

Indeed, "Baburname" is the most beloved and dynasty of Babur's heritage. World Orientalists attract the attention what this is one of the main reasons. Japanese scientist Eiji Mano notes that "Baburname" is so clear and informative that the learner of the subject will want to learn again and again, that is all treasure. Therefore, this work is really a source and treasure for the professionals in all fields" [7.P.117].

Archaisms have been used in ancient times and have alternatives already existing. We are faced with the archeology in the translations of ancient writings or in the writings of modern writers about the preceding period. Sometimes we do not have the option to refer by the dictionary. The archaic word for archeology and quality is explained in the explanatory dictionary of the Uzbek language as follows: "Archaism (from the Greek language to the Uzbek language from the Greek language) - lingv. outdated word, phrase, grammatical form. Archaic (in Russian: archaic, archaic) - outdated, abandoned, archaic, archaic term" [8.P.55]. Boboyev believes that "Archaism is the oldest synonym for active words. The form of the word is obsolete, but the meaning is preserved - it is another word" [1.P.182]. Archaic words and phrases are not understandable to all. It is understood only in the text itself, meaning in this text.

The study of archaeologists and their translations was carried out by E.Kilichev [9], N.Urmanova [10], Isakova Sh [3] and other scientists. At the time of the translation, opinions were expressed by our scientists in the French translation of archaisms and its translation.

The study of the translations the archaisms in the English language by "Baburname" is still not fully studied. That's why archaisms have been described as one of the means of illustration. We have made comparative studies on Leyden-Erskin, A.Beverij and W.Tekston's translations of how the archeology is reflected in English.

S.Vlaxov and S.Florin believe that the reader will face archaic words and phrases in the following cases: 1.The works of the past writers. 2. Contemporary writers in the translation of the works they wrote to the past [2.P.133].

"Baburname" is the first type of historical work. This can often be the case with archaic words. It describes the military strategy of its time, scientific achievements of a number of disciplines, mountains and lakes, lakes and rivers, diverse plants and animals, underground and surface wealth of nations, traditions, languages, literature and art of nations, etymology of some words. The word "Baburname" was not used by the author as archaic. However, the words used in the early part in Babur's period are also part in "Baburname" which according to the scope of the author's sphere of study. Some of the words reflecting modernity during Babur's epoch have become ours in our time as archaic. If there are archaic words in the image of an event, it is unclear to the reader in original language. They can know the meaning of this 
archaic word by the dictionary in classical literature sources.

In general, archaic words are one of the factors that determine the pragmatic character of the original text. According to G. Rahimov: "The translator's attempt to modernize the original pragmatic features of the work also causes the text to change. The time and location of the events described in the original, and the time and place of the translation events, are completely different. "When it comes to word translations, it is important to keep the meaning and content of the words" [5.P.90].

"Bu muddatda Boysunqur mirzo Turkistong'a Shayboniyxong'a, mutavotir kishilar yiborib, Shayboniyxonni ko'mak tilabdur. Qishloq uylari tayyor bo'lib qo'rg'onga kirduk. Shayboniyxon Turkistondin ilg'ab o'shul sahari bizning yurtumuz ustiga kelib turdi. Bizning cherikimiz yaqin emas edi. Qishloq maslahatig'a ba'zi Raboti Xojag 'a, ba'zi Kobudg'a, ba'zi Sherozg'a borib edilar" in "Baburname" (Baburname 2002; 58). All the words in the context are not archaism in terms of Babur's language. But today, the form of writing has become archaism, lexical and meaningful.

The word "mutanotir" in the text is understood to mean "ketma-ket kishilar (people of the ordinary)". This archaic word is reflected in the translations of LeydenErskin, A. Beverij and W.Tekston: "repeated messengers" (qayta-qayta xabar beruvchilar), in A.Beverij translation: "again and again" (yana va yana), W.Tekston, "a stream of people" (odamlar to'dasi) were given in translation of "Baburname". The translators interpreted this archaic word as each of the three translators in their own way. If we compare them with each other, it is given as archaic words in every translation. In terms of their pragmatic attributes, each one serves only one meaning. However, even if they translate into a semantic word in the text of the translation, they do not give meaning to the work. The translation of the Leiden-Erskin translation into other translations is pragmatic. In some cases, translators interpreted the archaic words to perfectly match the textual content.

The archaic word "Ko'mak tilabdur" was following expressed in translation text: it was given inviting him to come to his assistance" (uning yordamga kelishini taklif qilish) in Leyden-Erskin translation, "to ask help" (ёрдам суураш) in A.Beverij translation, "to request assistance" (yordam so'rab iltimos qilish).

Whether the translation in the text refers to the meaning of the archaic word, or whether there is any meaning in the text, we will use a comparative analys is to clarify this idea.

As it turned out, the translation of the A. Beverij translation into both texts is pragmatic compatible with the original. The translation of the word arcade corresponds to the text of the work semantically. For example, "Archaism is a phenomenon in the language, it is not clear to the speaker, but to the meaning of the context: it is only meaningful in this context, it does not give any idea when analyzing its particular elements" [3.P.94].

If analyzed the word "Kurgan": "fort" in Leyden-Erskine translation, "Khawaja Dildar" in A.Beverij translation, "fortress" in W.Tekston translation were showen. If Leyden-Erskin and W.Tekston brought the exact word «Kurgan», A.Beverij was satisfied with translating the name of the fortress in a transliteration manner.

The passage is "Turkistondin ilg'ab o'shul sahari" (Turkistondan jadallab o'sha tong) was translated "next morning...hastened" (keying tong tezlab) in Leyden-Erskine translation, "On the morning...ridden light" (tongda yorug'ning tez tushishi) in A.Beverij, "hastened...Wednesday morning" (Chorshanba kuni ertalab...tezlab) in W.Tekston translation. Thus, translators interpreted the archaic interpretation differently. In the translation of Leyden-Erskin and W.Tekston into pragmatic accordance, A.Beverij's translation was translated in a slight, pragmatic disadvantage, "On the morning ... Ridden light from Turkistan" (ertalabda yorug'ning tez tushishi).

The originality of the archeology in translation reflects the interpreter's understanding of the essence of the word, and that he is aware of the classical literature of the people in their original translation. It is also important for the translators to have a full recovery in the original texts of ancient archaic words, which have been used in the past. One of the functions of an interpreter is to grasp all the archaic words used in the text in the original language and to reflect exactly in the translation. The translator will be able to avoid confusion in the translation text if he / she is able to accomplish the assigned tasks.

Translations of classical literature often encounter archaism, emotionism, and realities. In the classic interpretation, especially arahisms, it is necessary to pay attention. Often, meaning and content of archaism is evident from context. If it does not have a synonym for the meaning of archaism, the translation may be distorted in meaning and content. The logic is a distraction of the interpreter. Their translations have to be interpreted and interpreted in some cases. Because the translation may not be an alternative to archaism.

In order for translators to avoid shortcomings, it is crucial that they understand the meaning of the archaic word and find its equivalent. Translator and interpreter E.Ochilov: "Another drawbacks for all translators are historic-archaic words, either in their own meaning or in 
use" [4.P.65]. In fact, the translation text can not be reached without knowing what the word means, without understanding the meaning of archaic words. It is important for the translator to avoid the occurrence of such circumstances and to try to avoid the scientific value of the translation text. Because of a translator error, text that has a scientific value should not be converted to a regular text. Only then does the interpreter intend for its intended purpose, and it will succeed it to the end.

The archaisms mentioned in the text are specifically translated into translation texts. The translator pays special attention to the translation of each archais $m$ in the text of the translation to reflect the meanings of the archaisms expressed in the text. In order to avoid distracting the reader and understanding the content of the text, and to avoid losing pragmatic features, translations of the archaeological texts should be properly interpreted. The confusion in the text diminishes the reader's interest in the bookstore or diminishes the text of the work. Granting such superficial creativity does not produce good results. In "Baburnama", there are many examples of the author who preceded the authorship of the sovereignty and the character of the contemporaries, the leaders of the army and the army, comparatively comparing his own worldview, his unique talent in the rule of the kingdom, and the colorful imagery to the reader through artistic, comparative images [11.p.131].

In conclusion it was found out that translation of archaisms in «Baburname" was connected with two factors. 1) Ancient Turkic words are widely used in Babur's language and style; 2) majority of words in use during the time when «Baburname» was written became archaic by now. Babur enriched the Turkic language by using archaisms with high level and artistically and provided «Baburname"'s high artistic value. These were expressed by abbreviations, in appropriate places by commentaries and explanations, adequate variants and archaic words peculiar to the English language in English translations.

\section{REFERENCES}

[1] Boboev T. Adabiyotshunoslik asoslari. - Toshkent: O'zbekistan, 2002. - B.182.

[2] Влахов С, Флорин С. Непереводимое в переводе. Издание третье. Исправленное. - М.: Валент, 2006. - C.133.

[3] Isaqova Sh. Badiiy tarjimada milliylik va tarixiylikning aks ettirilishi (Oybekning "Navoiy" nomanining frantsuzcha tarjimasi misolida). Filol. Fan.nom. ...diss. - Toshkent, 2004.

[4] Ochilov E. Tarjima nazariyasi va amaliyoti. Toshkent, 2016. - B.65.
[5] Rahimov G. Tarjima nazariyasi va amaliyoti. Toshkent: O'zbekiston milliy ensiklopediyasi. B.90.

[6] Xolmanova Z. "Boburnoma" leksikasi. - Toshkent: Fan, 2007. - B.24.

[7] Xoshimova D. "Boburnoma" asari yapon sharqshunoslari tadqiqida // Yosh Sharqshunoslarning Akademik Ubaydulla Karimov nomidagi XIV ilmiy-amaliy konferentsiyasi materiallari. -TToshkent, 2017. - B. 117.

[8] O'zbek tilining izohli lug'ati, 1-jild. - M.: Russkiy yazik, 1981. - B.55.

[9] Qilichev E. Ayniy prozasida arxaizm va istorizmlar: Avtoref. dis...kand. filol.nauk. - Toshkent, 1969.

[10] O'rmonova N. Tarjimada tarixiy-arxaik leksikani aks ettirish printsiplari va tarjima aniqligi (o'zbek adabiyotidan frantsuz tiliga qilingan tarjimalar tahlili asosida): Filol. fan. nom. ...diss. - Toshkent, 2008.

[11] Khoshimova Dildora Madaminovna. The Psychology of Character Expression and Descriptive Tools in Reflecting Translation. P.131. jels.com/detail/the-psychology-of-characterexpression-and-descriptive-tools-in-reflectingtranslation/ 